\title{
A SELECTIVE MEDIUM FOR STREPTOCOCCUS MUTANS
}

\author{
Olga G. Gold, H. V. Jordan and J. van Houte \\ Forsyth Dental Center, Boston, Massachusetts 02115, U.S.A.
}

\begin{abstract}
Summary-A selective medium was developed for the isolation of Streptococcus mutans from human dental plaque. Mitis-salivarius agar was modified by adding 0.2 units $/ \mathrm{ml}$ bacitracin and by increasing the sucrose concentration to 20 per cent. At these concentrations, the selective agents allowed the undiminished recovery of Strep. mutans with maximum inhibition of the balance of the streptococcal flora normally encountered on this medium. Enterococci or yeasts were sometimes observed upon direct culturing of plaque samples from children with advanced dentinal lesions.
\end{abstract}

\section{INTRODUCTION}

THE ASSOCIATION of Streptococcus mutans with dental caries was first reported by Clarke (1924) who isolated the organism, frequently in pure culture, from the depth of carious lesions. In recent years, this organism has become the subject of considerable investigation since its caries-inducing potential was demonstrated in animal models (Fitzgerald, Jordan and Stanley, 1960; FitzGerald and Keyes, 1960). Studies which are concerned with elucidating the aetiologic role of Strep. mutans in dental caries have been hampered, however, by the lack of convenient and reliable techniques for the recognition and enumeration of the organisms in human dental plaque. A method generally used involves the culturing of plaque samples on mitis-salivarius agar which is selective for streptococci (KRASSE, 1966; JoRdAN, KRASSE and MöLLER, 1968). It is possible to differentiate Strep. mutans from the other streptococci on this medium on the basis of its unique colonial appearance. This procedure can be tedious when large numbers of samples are involved. Furthermore, the presence of Strep. mutans cannot be established on this medium with any degree of reliability when it constitutes only a small percentage of the total streptococcal flora.

Special media for the selective cultivation of Strep. mutans have been described previously. CARLSSON (1967) has described a medium containing sulphadimctinc, which is based on the relative resistance of this species to the sulpha drugs. IKEDA and SANDHAM (1972) have reported the selective growth of Strep. mutans on mitis-salivarius agar containing 40 per cent sucrose. However, the concentration of these agents, that had to be used for the selection of Strep. mutans, either did not completely inhibit other organisms, or partially inhibited Strep. mutans.

In the present report, a selective medium for Strep. mutans is described which utilizes two selective agents, sucrose and bacitracin. The relative resistance of Strep. mutans to high concentrations of sucrose has been reported (GFHRING, 1968; IKFDA and SANDHAM, 1972). Bacitracin sensitivity has been used as a differential characteristic 
in classification schemes for the streptococci (Colman, 1968). Lancefield group D streptococci (LANCEFIELD, 1933) are relatively resistant to the action of bacitracin (ToAlA et al., 1969). Although Strep. mutans does not react with group D antiserum, this species shares many characteristics of Streptococcus bovis (DE STOPPELAAR, VAN HouTE and DE MOOR, 1967) which raised the possibility that Strep. mutans might also share the property of bacitracin-resistance of the group D streptococci. In fact, CARLSSON (1968) had reported that 7 out of 9 Strep. mutans strains were resistant to 5 units/ml of bacitracin. Seventy-nine per cent of the other streptococcal strains, similarly tested, were sensitive to bacitracin.

\section{MATERIALS AND METHODS}

The development of a selective medium for Strep. mutans was conducted in three phases. 1 . Mitissalivarius agar (Difco) was investigated for its adequacy in allowing full recovery of Strep. mutans. 2. Selective agents were tested separately, utilizing pure cultures to determine optimal concentrations for suppression of other streptococci without inhibition of Strep. mutans. 3. The medium, containing a combination of selective agents at optimal concentrations, was evaluated for its ability to support selective recovery of Strep. mutans from human dental plaque.

\section{Culture media}

Mitis-salvarius agar was tested, with one or more of the following additions, in an attempt to increase the recovery of Strep. mutans grown as pure cultures: Phytone (BBL), Polypeptonc (BBL), Bacto Peptone (Difco), Myosate (BBL), Trypticase (BBL), all at 1 per cent concentration; beef extract (Difco) at 0.3 per cent and yeast extract (Difco) at 0.2 per cent. The inhibitors, crystal violet, trypan blue and potassium tellurite, in mitis-salivarius agar, were also tested for their effect on the growth of pure cultures of Strep. mutans by their successive deletion from the medium.

The recovery of Strep. mutans from dental plaque was compared on heart-infusion agar (Difco) with 5 per cent defibrinated sheep blood, MM10 medium (SYED and LOESCHE, 1972), mitis-salivarius agar and the selective medium developed.

\section{Selective agents}

Representative Strep. mutans strains, and strains of other oral streptococci, were tested to determine the optimal concentration of selective agents that would allow undiminished recovery of the former, and maximum suppression of the latter.

Sucrose (Fisher Scientific Co.) was incorporated into mitis-salivarius agar before sterilization over a range of $10-40$ per cent $\mathrm{w} / \mathrm{v}$. Bacitracin was incorporated in mitis-salivarius agar in increasing concentrations from 0.06 to $2.0 \mathrm{units} / \mathrm{ml}$ of the medium after sterilization. The bacitracin stock solution was made up in sterile distilled water under aseptic conditions with a minimum of agitation.

\section{Microorganisms}

One representative from each of the five serological groups of Strep. mutans (BRATTHALL, 1970) was used for the development of the medium. These were strains AHT (ZINNER et al., 1965), FA-1 (FITZGerald et al., 1960), NCTC 10449 (EdWARdsson, 1968), SL-1 (FitZGerald and Jordan, 1968) and B2 (EDWARDSSON, 1968). In addition to the above Strep. mutans strains, the following laboratory strains were used: Streptococcus sanguis $\mathrm{H} 4$ and Streptococcus salivarius $\mathrm{H} 5$, both isolated from human dental plaque, Streptococcus mitis 26 (LiLJEMARK and GrbBons, 1972) and Streptococcus faecalis $\mathrm{N} 83$.

\section{Pure culture studies}

Pure cultures were grown and maintained in trypticase soy broth (BBL). Cultures were grown under an atmosphere of 95 per cent nitrogen and 5 per cent carbon dioxide for $18 \mathrm{hr}$. Ten-fold dilutions were made in $9 \mathrm{ml}$ phosphate buffer $0.067 \mathrm{M}, \mathrm{pH} 7 \cdot 2$. Duplicate samples of $0.1 \mathrm{ml}$ were plated from $10^{-6}$ and $10^{-7}$ dilutions and spread on the surface of the medium with a sterile, bent, glass rod.

\section{Plaque sampling}

Pooled plaque samples were collected from approximal tooth surfaces of 12-14-yr-old school 
children, using sterile dental floss. The floss was immediately placed in a small screw-capped vial containing $3 \mathrm{ml}$ of VMG II transport medium (MöLLER, 1966). The vials were agitated on a Vortex test-tubc mixcr (Scicntific Industrics Inc., Springfield, Mass.) for $30 \mathrm{sec}$ in order to dislodge the plaque from the floss and to obtain a homogeneous suspension. Ten-fold dilutions of the suspensions were made in 0.05 per cent yeast-extract water. Duplicate $0.1 \mathrm{ml}$ samples of the dilutions were plated and spread on the medium with a sterile, bent, glass rod.

All plates, from pure culture and plaque sampling studies, were incubated under an atmosphere of 95 per cent nitrogen and 5 per cent carbon dioxide for $24 \mathrm{hr}$ at $37^{\circ} \mathrm{C}$. After incubation, the plates were allowed to stand at room temperature for $24 \mathrm{hr}$. The plates were then examined, at a magnification of $\times 15$, using a wide-field dissecting microscope.

\section{Enumeration and identification}

Total counts were determined using the Quebec colony counter. Streptococcus mutans colonies were identified and counted under the dissecting microscope on plates with 30-300 colonies, whenever possible. Colonial characteristics of Strep. mutans on blood agar with sucrose and MM10 agar were similar to the appearance of this species on mitis-salivarius agar as described by KRASSE (1966). Representative colonies typical of Strep. mutans, as well as those whose identity as Strep. mutans was doubtful, were subcultured to test the ability of the strains to ferment mannitol and sorbitol and to determine their colonial morphology on mitis-salivarius agar.

\section{RESULTS}

Initial experiments with representative strains of Strep. mutans suggested that mitis-salivarius agar was nutritionally adequate and non-inhibitory for this species. Comparable colony counts were obtained on mitis-salivarius agar, with and without the inhibitory agents, crystal violet, trypan blue and tellurite, which are usually incorporated in this medium. No increase in colony counts was observed when phytone, polypeptone, bacto peptone, myosate, trypticase, beef extract or yeast were added to mitis-salivarius agar. Pure cultures of Strep. mutans, and dental plaque samples cultured in parallel on mitis-salivarius agar and on other rich nonselective media, showed no advantage of the latter over mitis-salivarius agar. Some examples of the results from experiments, in which mitis salivarius agar was compared to heartinfusion agar with 5 per cent defibrinated sheep blood and 5 per cent sucrose, are shown in Table 1. The data indicate that the recovery of Strep. mutans from dental plaque samples was similar on both media. In further studies of the development of a selective medium for Strep. mutans, mitis-salivarius agar was therefore used as a basal medium.

TABle 1. COMPARATIVE RECOVERIES OF Streptococcus mutans From humaN DENTAL PLAQUE ON BLOOD AGAR AND MITIS-SALIVARIUS AGAR

\begin{tabular}{ccc}
\hline Plaque number & Blood agar & Mitis-salivarius agar \\
\hline 1 & $63^{*}$ & 83 \\
2 & 380 & 430 \\
3 & 53 & 50 \\
4 & 45 & 41 \\
5 & 58 & 67 \\
\hline
\end{tabular}

* Mean number of Strep. mutans colonies on duplicate plates from $0.1 \mathrm{ml}$ of a $10^{-3}$ dilution of plaque collected in VMG II transport medium. Individual counts never exceeded \pm 13 per cent of the mean.

Studies with five strains of Strep. mutans representing the different serotypes demonstrated that all tolerated concentrations of sucrose up to 20 per cent in mitissalivarius agar without any adverse effects on their growth or colonial morphology (Table 2). Strains AHT, FA-1 and NCTC 10449 grew in the presence of sucrose 
concentrations up to 40 per cent with only a moderate decrease in numbers at the higher sucrose levels. However, strains SL-1 and B2 were more sensitive to the higher sucrose concentrations. The laboratory strain of Strep. sanguis was completely inhibited at a level of 15 per cent sucrose in mitis-salivarius agar. The Strep. salivarius and Strep. mitis laboratory strains were more resistant, being inhibited by 35 and 20 per cent sucrose respectively.

TABLE 2. EFFECT OF SUCROSE ON PURE CULTURes OF ORAL STREPTOCOCCI

\begin{tabular}{|c|c|c|c|c|c|c|c|c|}
\hline \multirow{2}{*}{$\begin{array}{l}\text { Sucrose concentration } \\
\text { in mitis-salivarius agar } \\
\text { (per cent) }\end{array}$} & \multicolumn{4}{|c|}{ Strep. mutans } & & \multirow{2}{*}{$\begin{array}{l}\text { Strep. } \\
\text { sanguis } \\
\mathrm{H} 4\end{array}$} & \multirow{2}{*}{$\begin{array}{l}\text { Strep. } \\
\text { saltuarius } \\
\text { HS }\end{array}$} & \multirow{2}{*}{$\begin{array}{l}\text { Strep. } \\
\text { mitis } \\
26\end{array}$} \\
\hline & AHT & FA-1 & 10449 & SL-1 & B2 & & & \\
\hline $\begin{array}{r}5 \\
10 \\
15 \\
20 \\
25 \\
30 \\
35 \\
40\end{array}$ & $\begin{array}{c}169^{*} \\
184 \\
164 \\
161 \\
181 \\
126 \\
96 \\
91\end{array}$ & $\begin{array}{l}279 \\
298 \\
235 \\
269 \\
120 \\
156 \\
107 \\
102\end{array}$ & $\begin{array}{l}88 \\
92 \\
95 \\
95 \\
69 \\
80 \\
71 \\
73\end{array}$ & $\begin{array}{r}30 \\
25 \\
41 \\
45 \\
28 \\
32 \\
12 \\
0\end{array}$ & $\begin{array}{r}100 \\
105 \\
108 \\
108 \\
110 \\
91 \\
0 \\
0\end{array}$ & $\begin{array}{r}43 \\
37 \\
0 \\
0 \\
0 \\
0 \\
0 \\
0\end{array}$ & $\begin{array}{r}127 \\
123 \\
128 \\
106 \\
39 \\
1 \\
0 \\
0\end{array}$ & $\begin{array}{r}132 \\
69 \\
46 \\
0 \\
0 \\
0 \\
0 \\
0\end{array}$ \\
\hline
\end{tabular}

* Mean number of colonies on duplicate plates from $0.1 \mathrm{ml}$ of a $10^{-6}$ dilution.

Pure cultures of Strep. mutans grew on mitis-salivarius agar containing up to 2 units/ml bacitracin, which was the maximum level tested (Table 3). With some of the strains a reduction in numbers was observed above 0.25 units $/ \mathrm{ml}$. Streptococcus salivarius, strain H5 and Strep. mitis, strain 26 were completely inhibited at 0.25 and 0.125 units/ml respectively. Streptococcus sanguis, strain H4 was more resistant to bacitracin. Although a gradual reduction in numbers occurred as the bacitracin concentration was increased, complete inhibition was not achieved below $2 \mathrm{units} / \mathrm{ml}$. The data in Table 3 indicate that the optimum concentration of bacitracin, which would allow the selective growth of Strep. mutans, was between 0.125 and 0.25 units/ml.

TABle 3. EFFect of bacitracin ON PURE culture of ORAL STREPTOCOCCI

\begin{tabular}{|c|c|c|c|c|c|c|c|c|}
\hline \multirow{2}{*}{$\begin{array}{c}\text { Bacitracin concentration } \\
\text { in mitis-salivarius agar } \\
\text { (units/ml) }\end{array}$} & \multicolumn{5}{|c|}{ Strep. mutans } & \multirow{2}{*}{$\begin{array}{l}\text { Strep. } \\
\text { sanguis } \\
\text { H4 }\end{array}$} & \multirow{2}{*}{$\begin{array}{l}\text { Strep. } \\
\text { salivarius } \\
\text { H5 }\end{array}$} & \multirow{2}{*}{$\begin{array}{c}\text { Strep. } \\
\text { mitis } \\
26\end{array}$} \\
\hline & AHT & FA-1 & 10449 & SL-1 & B2 & & & \\
\hline $\begin{array}{l}0 \\
0.0625 \\
0.125 \\
0.25 \\
0.5 \\
1 \\
2\end{array}$ & $\begin{array}{l}235^{*} \\
232 \\
262 \\
237 \\
245 \\
214 \\
205\end{array}$ & $\begin{array}{r}200 \\
191 \\
196 \\
191 \\
182 \\
181 \\
58\end{array}$ & $\begin{array}{l}236 \\
231 \\
220 \\
197 \\
212 \\
194 \\
183\end{array}$ & $\begin{array}{l}62 \\
58 \\
60 \\
51 \\
35 \\
42 \\
35\end{array}$ & $\begin{array}{r}125 \\
119 \\
107 \\
112 \\
72 \\
82 \\
75\end{array}$ & $\begin{array}{r}184 \\
110 \\
109 \\
97 \\
82 \\
8 \\
0\end{array}$ & $\begin{array}{r}36 \\
28 \\
18 \\
0 \\
0 \\
0 \\
0\end{array}$ & $\begin{array}{r}170 \\
103 \\
0 \\
0 \\
0 \\
0 \\
0\end{array}$ \\
\hline
\end{tabular}

* Mean number of colonies on duplicate plates from $0.1 \mathrm{ml}$ of a $10^{-6}$ dilution.

On the basis of the data obtained with pure cultures, the recovery of Strep. mutans from human dental plaque samples was studied on mitis-salivarius agar, to which $0.05-0.2$ units $/ \mathrm{ml}$ of bacitracin were added, either singly, or in combination with, 20 per cent sucrose. Each sample was simultaneously cultured on mitis-salivarius agar without additions. As shown with some examples in Table 4, virtually complete inhibition of bacteria, other than Strep. mutans, was obtained with mitis-salivarius 
agar containing 20 per cent sucrose and 0.2 units $/ \mathrm{ml}$ bacitracin. Lower concentrations of bacitracin, alone or in combination with 20 per cent sucrose, were not completely effective.

In view of these results, the selective medium (MSB) was formulated to contain $\mathbf{0 . 2}$ units of bacitracin $/ \mathrm{ml}$ of medium and 20 per cent sucrose and was prepared as follows: To $1000 \mathrm{ml}$ reconstituted mitis-salivarius agar, $150 \mathrm{~g}$ of sucrose was added. The medium was heated to dissolve the components and then autoclaved at $121^{\circ} \mathrm{C}$ for $15 \mathrm{~min}$. The medium was then cooled to $45^{\circ} \mathrm{C}$ after which $1 \mathrm{ml}$ of each of the sterile stock solutions ( 1 per cent tellurite and 200 units/ml bacitracin) was added. The

TABLE 4. SELECTIVE RECOVERY OF Strep, mutans FROM HUMAN DENTAL RLAQUE ON MITIS-SALIVARIUS AGAR CONTAINING VARIOUS CONCENTRATIONS OF BACITRACN AND SUCROSE

\begin{tabular}{|c|c|c|c|c|c|c|c|c|c|c|}
\hline \multirow[b]{3}{*}{$\begin{array}{l}\text { Additions to mitis- } \\
\text { salivarius agar }\end{array}$} & \multicolumn{10}{|c|}{ Plaque number } \\
\hline & \multicolumn{2}{|c|}{1} & \multicolumn{2}{|c|}{2} & \multicolumn{2}{|c|}{3} & \multicolumn{2}{|c|}{4} & \multicolumn{2}{|c|}{5} \\
\hline & $\begin{array}{l}\text { Strep. } \\
\text { mutans }\end{array}$ & $\begin{array}{c}\text { Other } \\
\text { bacteria }\end{array}$ & $\begin{array}{l}\text { Strep. } \\
\text { mutans }\end{array}$ & $\begin{array}{c}\text { Other } \\
\text { bacteria }\end{array}$ & $\begin{array}{l}\overline{\text { Strep. }} \\
\text { mutans }\end{array}$ & $\begin{array}{c}\text { Other } \\
\text { bacteria }\end{array}$ & $\begin{array}{l}\text { Strep. } \\
\text { mutans }\end{array}$ & $\begin{array}{c}\text { Other } \\
\text { bacteria }\end{array}$ & $\begin{array}{l}\text { Strep. } \\
\text { mutans }\end{array}$ & $\begin{array}{c}\text { Other } \\
\text { bacteria }\end{array}$ \\
\hline $\begin{array}{l}\text { None } \\
0.05 \text { unit/ml } \\
\text { Bacitracin and } \\
20 \% \text { sucrose }\end{array}$ & $\underset{300}{\text { N.D.* }}$ & $\begin{array}{l}>300 \\
>100\end{array}$ & $\begin{array}{l}\text { N.D. } \\
>\mathbf{3 0 0}\end{array}$ & $\begin{array}{l}300 \\
35 \dagger\end{array}$ & $\underset{>300}{\text { N.D. }}$ & $>\begin{array}{r}300 \\
7\end{array}$ & $\begin{array}{l}\text { N.D. } \\
>\mathbf{3 0 0}\end{array}$ & $>\begin{array}{r}300 \\
13\end{array}$ & $\begin{array}{l}\text { N.D. } \\
\text { N.D. }\end{array}$ & $\begin{array}{l}>300 \\
>1000\end{array}$ \\
\hline $\begin{array}{l}0.1 \text { unit } / \mathrm{ml} \text { Bacitracin } \\
0.1 \text { unit } / \mathrm{mlBacitracin}\end{array}$ & $\begin{array}{l}\text { N.D. } \\
>\mathbf{3 0 0}\end{array}$ & $\begin{array}{c}>300 \\
80\end{array}$ & $\begin{array}{l}>300 \\
>300\end{array}$ & $\begin{array}{l}93 \\
43\end{array}$ & $\begin{array}{l}>300 \\
>300\end{array}$ & $\begin{array}{r}80 \\
7\end{array}$ & $\begin{array}{l}>300 \\
>300\end{array}$ & $\begin{array}{c}100 \\
27\end{array}$ & $\begin{array}{l}\text { N.D. } \\
\text { N.D. }\end{array}$ & $\begin{array}{l}>300 \\
>300\end{array}$ \\
\hline $\begin{array}{l}0.2 \text { unit } / \mathrm{ml} \text { Bacitracin } \\
0.2 \text { unit/ml Bacitracin } \\
\text { and } 20 \% \text { sucrose }\end{array}$ & $\begin{array}{l}\text { N.D. } \\
>\mathbf{3 0 0}\end{array}$ & $\begin{array}{r}300 \\
0\end{array}$ & $\begin{array}{l}>300 \\
>300\end{array}$ & $\begin{array}{r}60 \\
0\end{array}$ & $\begin{array}{l}>300 \\
>300\end{array}$ & $\begin{array}{r}57 \\
0\end{array}$ & $\begin{array}{l}>300 \\
>300\end{array}$ & $\begin{array}{r}65 \\
0\end{array}$ & N.D. & $>300$ \\
\hline
\end{tabular}

* N.D. Not detectable, plates too crowded.

+ Mean number of colonies on duplicate plates from $0.1 \mathrm{ml}$ of VMG II transport medium containing plaque material.

bacitracin solution is stable for 1 week, if stored in the refrigerator. The flask containing the medium was gently swirled to mix the contents thoroughly without foaming. Plates were poured with approximately $20 \mathrm{ml}$ of the medium and then permitted to dry for $24 \mathrm{hr}$ at room temperature. After drying, plates were stored in the refrigerator until use.

The comparative recoveries of Strep. mutans, from diluted dental plaque samples, cultured in parallel on MM10 agar, mitis-salivarius and MSB agar, the selective medium with 20 per cent sucrose and $0 \cdot 2$ units $/ \mathrm{ml}$ bacitracin, are shown in Table 5 . No differences were observed in the number of Strep. mutans colonies that could be cultivated on MSB agar as compared to MM10 agar. The colonial morphology of

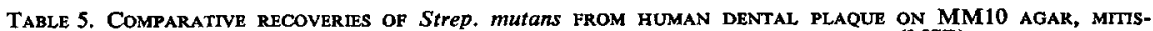
SALIVARIUS AGAR AND MTIIS-SALIVARIUS WITH SUCROSE AND BACITRACIN (MSB)

\begin{tabular}{|c|c|c|c|c|c|c|}
\hline \multirow[b]{2}{*}{$\begin{array}{l}\text { Plaque } \\
\text { number }\end{array}$} & \multicolumn{2}{|c|}{ MM 10} & \multicolumn{2}{|c|}{ Mitis-salivarius } & \multicolumn{2}{|c|}{ MSB } \\
\hline & $\begin{array}{l}\text { Strep. } \\
\text { mutans }\end{array}$ & $\begin{array}{l}\text { Other } \\
\text { bacteria }\end{array}$ & $\begin{array}{l}\text { Strep. } \\
\text { mutans }\end{array}$ & $\begin{array}{l}\text { Other } \\
\text { bacteria }\end{array}$ & $\begin{array}{l}\text { Strep, } \\
\text { mutans }\end{array}$ & $\begin{array}{l}\text { Other } \\
\text { bacteria }\end{array}$ \\
\hline $\begin{array}{l}1 \\
2 \\
3 \\
4 \\
5\end{array}$ & $\begin{array}{r}3 * \\
26 \\
117 \\
15 \\
47\end{array}$ & $\begin{array}{r}228 \\
>300 \\
>300 \\
121 \\
>300\end{array}$ & $\begin{array}{l}7 \\
\text { N.D.t } \\
106 \\
12 \\
46\end{array}$ & $\begin{array}{r}96 \\
>300 \\
>300 \\
24 \\
>300\end{array}$ & $\begin{array}{r}6 \\
24 \\
100 \\
37 \\
40\end{array}$ & $\begin{array}{l}1 \\
0 \\
0 \\
0 \\
0\end{array}$ \\
\hline
\end{tabular}

* Mean number of colonies on duplicate plates from $0.1 \mathrm{ml}$ of a $10^{-3}$ dilution of plaque in VMG II transport medium Individual counts of Strep. mutans varied less than \pm 30 per cent from the mean except in plaque number 1 ( \pm 50 per cent) due to the low numbers of Strep. mutans.

+ N.D. Not detectable, plates too crowded. 
Strep. mutans, on the three media, was similar. The superiority of MSB agar over mitis-salivarius agar, in recovering small numbers of Strep. mutans, is clearly demonstrated in the case of plaque sample 2. Streptococcus mutans could not be detected on the crowded mitis-salivarius plate. Bacteria, other than Strep.mutans, were virtually all inhibited when MSB agar was used. When undiluted plaque samples were cultured, MSB agar was clearly superior to the other two media. Confluent bacterial growth on MM10 agar and mitis-salivarius agar prevented detection of Strep. mutans colonies. Other experiments involving dental plaque, saliva and samples from the dorsum of the tongue, from many different subjects have shown that even a few colony-forming units of Strep. mutans, present in total populations of $10^{7}-10^{8}$ bacteria, can be easily detected on the MSB medium.

Occasionally enterococci and yeasts were encountered when undiluted samples of plaque, from advanced dentinal lesions, saliva or samples from the dorsum of the tongue, were cultured. The colonies of the enterococci were dark blue to brown and flat while the yeasts appeared as large white to light blue matte colonies. All were easily differentiated from Strep. mutans by colonial appearance. A laboratory strain of Strep. faecalis (N83) was capable of uninhibited growth on MSB medium.

\section{DISCUSSION}

Previous selective media relied on single selective agents to which Strep. mutans was relatively resistant. In contrast, the present work was based on the assumption that different selective agents for Strep. mutans exhibiting different inhibitory actions could be utilized to complement each other. This approach might permit the use of the individual agents, in combination, whereby concentrations of each agent, noninhibitory to Strep. mutans, would be sufficient to obtain complete suppression of other bacteria.

Optimum levels of sucrose and bacitracin were determined with pure cultures, on the basis of maximum inhibition of other streptococci without inhibition of Strep. mutans. At the optimal sucrose concentration (20 per cent) finally selected, Strep. sanguis and Strep. mitis were effectively inhibited but Strep. salivarius was not completely suppressed. In contrast, the optimal concentration of bacitracin selected $(0.2 \mathrm{units} / \mathrm{ml})$ was sufficient for the complete elimination of Strep. salivarius and Strep. mitis but studies with pure cultures indicated that Strep. sanguis was not completely inhibited at this concentration. Neither of these agents, at their optimum levels, interfered with the growth of Strep. mulans. A combination of sucrose and bacitracin incorporated in mitis-salivarius agar, at the optimal levels determined as above, was effective in inhibiting bacteria other than Strep. mutans when human dental plaque samples were cultured.

Mitis-salivarius agar seemed a logical starting point for the development of a selective medium for the isolation of Strep. mutans since the medium is already selective for the streptococci and because the colonial appearance of Strep. mutans is quite distinctive on this medium. In addition, mitis-salivarius agar is commerically available which would assure its ready accessibility, particularly to smaller laboratories with limited facilities for medium preparation. 
To date, the only interfering organisms detected on MSB agar have been low numbers of enterococci and yeasts which developed when undiluted samples from various sites in the mouth, and plaques from children with advanced dentinal lesions, were cultured. These organisms are rarely encountered in routine plaque sampling at the dilutions commonly employed and are easily differentiated on the basis of their colonial morphology. Thus they should not constitute a problem in a routine use of the selective medium.

Development of a selective medium for Strep. mutans allows the isolation of this species from samples when present in low numbers relative to the total population. Studies on the transmission, epidemiology and general ecology of this species should be more feasible now than with the less sensitive cultural methods previously available, In fact, it may be necessary to re-evaluate previous studies on the presence and distribution of Strep. mutans in human populations (KRASSE et al., 1968; JoRDAN. ENGlander and Lim, 1969; De StOPPelaAR, van Houte and BaCKer DirKs, 1969). Also, the scope of these clinical studies can be significantly expanded since a reliable selective medium should permit the processing of larger numbers of samples by less skilled personnel.

Acknowledgements-This investigation was supported by Grant DE-02847 from the National Institute of Dental Research.

Résumé-Un milieu sélectif pour l'isolement du Streptococcus mutans de la plaque dentaire humaine a été mis au point. Le mitis salivarius agar a été modifié en ajoutant 0,2 unités $/ \mathrm{ml}$ de bacitracine et en augmentant la concentration de saccharose de 20 pour cent. A ces concentrations, les agents sélectifs permettent d'obtenir un maximum de Strep. mutans, avec une inhibition élevée du reste de la flore streptococcique normalement présente dans le milieu. Les entérocoques et les levures sont parfois présents en culture directe d'échantillons de plaques d'enfants présentant des lesions dentinaires avancées.

Zusammenfassung-Zur Isolation von Streptococcus mutans aus menschlicher Zahnplaque wurde ein selektives Medium entwickelt. Durch Zusatz von $0,2 \mathrm{E} . / \mathrm{ml}$ Bacitracin und durch Erhöhung der Rohrzuckerkonzentration auf 20 Prozent wurde der Mitis-Salivarius Agar modifiziert. Bei diesen Konzentrationen der selektiven Wirkstoffe war es möglich, Strep. mutans unvermindert zurückzugewinnen bei gleichzeitiger maximaler Hemmung des in diesem Medium normalerweise vorhandenen Gleichgewichts der Streptokokkenflora. Bei direkter Kultivierung von Plaqueproben von Kindern mit fortgeschrittenen Dentinläsionen wurden gelegentlich Enterokokken oder Hefen beobachtet.

\section{REFERENCES}

Bratthall, D. 1970. Demonstration of five serological groups of streptococcal strains resembling Streptococcus mutans. Odont. Revy 21, 143-152.

CARLsSon, J. 1968. A numerical taxonomic study of human oral streptococci. Odont. Revy 19 ; $137-160$.

Carlsson, J. 1967. A medium for isolation of Streptococcus mutans. Archs oral Biol. 12, 1657-1658.

Clarke, J. K. 1924. On the bacterial factor in the aetiology of dental caries. Br. J, exp. Pathol. 5, 141-147.

Colman, G. 1968. The application of computers to the classification of streptococci.J. gen. Microbiol. 50, $149-158$.

EDwardsson, S. 1968. Characteristics of caries-inducing lunnan streptococii resennbling Streptococcus mutans. Archs oral Biol. 13, 637-646. 
Fitzgerald, R. J. and Jordan, H. V. 1968. Polysaccharide producing bacteria and caries. In: Art and Science of Dental Caries Research (edited by HARRIS, R. S.) pp. 79-86. Academic Press, New York.

FitzGerald, R. J., Jordan, H. V. and Stanley, H. R. 1960. Experimental caries and gingival pathologic changes in the gnotobiotic rat. J. dent. Res. 39, 923-935.

Fitzgerald, R. J. and Keyes, P. H. 1960. Demonstration of the etiologic role of streptococci in experimental caries in the hamster. J. Am. dent. Ass. 61, 9-19.

GeHRING, G. 1968. Uber das Wachstum einiger Zahnplaque-streptokokken auf fester und in flussigen Nahrmedien mit verschiedenen zuckerkonzentrationen. Dt. Zahn. 23, 914-923.

IKEDA, T. and SANDHAM, H. J. 1972. A high sucrose medium for the identification of Streptococcus mutans. Archs oral Biol. 17, 781-783.

Jordan, H. V., Englander, H. R. and Lim, S. 1969. Potentially cariogenic streptococci in selected population groups in the western hemisphere. $J$. Am. dent. Ass. 78, 1131-1135.

Jordan, H. V., Krasse, B. and Moller, A. 1968. A method of sampling human dental plaque for certain "caries-inducing" streptococci. Archs oral Biol. 13, 919-927.

KRASSE, B. 1966. Human streptococci and experimental caries in hamsters. Archs oral Biol. 11, $429-436$.

Krasse, B., Jordan, H. V., Edwardsson, S., Svensson, I. and Trell, L. 1968. The occurrence of certain "caries-inducing" streptococci in human dental plaque material. Archs oral Biol. 13, 911-918.

LANCEHIELD, R. C. 1933. A serological differential of human and other groups of hemolytic streptococci. J. exptl Med. 57, 571-595.

Liljemark, W. F. and GibBons, R. J. 1972. Proportional distribution and relative adherence of Streptococcus miteor (mitis) on various surfaces in the human oral cavity. Infect. Immun. 6, 852-859.

MöLleR, A. J. R. 1966. Microbiological examination of root canals and periapical tissues of human teeth. Odont. Tidskr 74, No. 5-6, special article.

de StoppelaAr, J. D., van Houte, J. and Backer Dirks, O. 1969. The relationship between extracellular polysaccharide-producing strepococci and smooth surface caries in 13-yr-old children. Caries Res. 3, 190-199.

de StoppelaAr, J. D., van Houte, J. and DeMoor, C. E. 1967. The presence of dextran forming bacteria resembling Streptococcus bovis and Streptococcus sanguis in human dental plaque. Archs oral Biol. 12, 1199-1201.

SYED, S. A. and Loesche, W. J. 1972. Survival of human dental plaque flora in various transport media. Appl. Microbiol. 24, 638-644.

Toala, P., McDonald, A., Wilcox, C. and Finland, M. 1969. Susceptibility of Group D Streptococcus (enterococcus) to 21 antibiotics in vitro, with special reference to species differences. Am. J. med. Sci. 258, 416-430.

ZinNer, D., JABlon, J., ARAN, A. and SASLAW, M. 1965. Experimental caries induced in animals by streptococci of human origin. Proc. Soc. exp. Biol. 118, 766-770. 